\title{
Physicochemical Parameters and Fish Assemblages in the Downstream River of a Tropical Hydroelectric Dam Subjected to Diurnal Changes in Flow
}

\author{
Lee Nyanti $\mathbb{D},{ }^{1}$ Noor-Iskandar Noor-Azhar, ${ }^{1}$ Chen-Lin Soo $\mathbb{D}^{1},{ }^{1}$ Teck-Yee Ling $\mathbb{D},{ }^{1}$ \\ Siong-Fong Sim $\mathbb{D},{ }^{1}$ Jongkar Grinang, ${ }^{2}$ Tonny Ganyai, ${ }^{3}$ and Karen-Suan-Ping Lee ${ }^{3}$ \\ ${ }^{1}$ Faculty of Resource Science and Technology, Universiti Malaysia Sarawak, 94300 Kota Samarahan, Sarawak, Malaysia \\ ${ }^{2}$ Institute of Biodiversity and Environmental Conservation, Universiti Malaysia Sarawak, 94300 Kota Samarahan, Sarawak, Malaysia \\ ${ }^{3}$ Research and Development Department, Sarawak Energy Berhad, 93050 Kuching, Sarawak, Malaysia
}

Correspondence should be addressed to Lee Nyanti; nyantilee@gmail.com

Received 8 November 2017; Accepted 8 March 2018; Published 18 April 2018

Academic Editor: Michel Couderchet

Copyright ( $\odot 2018$ Lee Nyanti et al. This is an open access article distributed under the Creative Commons Attribution License, which permits unrestricted use, distribution, and reproduction in any medium, provided the original work is properly cited.

The downstream river of the tropical Batang Ai Dam is experiencing diurnal flow fluctuation due to power generation operation. Three samplings were conducted to collect the water quality and fish assemblage data and one sampling was conducted to study the hydrological characteristics of the downstream river. The results show that the downstream river is extremely shallow and moves slowly when the power generation is halted and no water is discharged from the powerhouse. Significant correlations between river flow and $\mathrm{pH}$, dissolved oxygen (DO), total suspended solids (TSS), and five-day biochemical oxygen demand $\left(\mathrm{BOD}_{5}\right)$ indicated that those parameters were influenced by the water discharge regulation. Fish abundance was low in upstream segment but it gradually increased as distance from the dam increased and was significantly correlated with DO. Fish diversity in the downstream river was influenced by the river depth and chlorophyll a concentration. The most abundant fish species, Cyclocheilichthys apogon, exhibited a negative allometric growth pattern, while Hampala macrolepidota and Hemibagrus planiceps exhibited an isometric growth pattern. Fulton's condition factor $(K)$ values for $89.4 \%$ of $H$. planiceps were $\leq 1$, indicating poor to extremely poor conditions.

\section{Introduction}

Impoundment of a river often causes dramatic changes in the physicochemical characteristics and biological structure of its downstream river [1-5]. Studies have shown that connectivity disruptions coupled with erratic flow pattern change the morphology and physicochemical characteristics of a river [6-11]. Domination of fish species that is well adapted to the new environment and elimination of sensitive species could alter the composition of fish assemblages and lower the fish diversity in the downstream river $[12,13]$.

In Malaysia, about 80 dams have been built and hydropower dams are the most common in the state of Sarawak [14]. As more hydroelectric dams are being planned in the state of Sarawak, there has been an increased effort to understand the impacts of hydroelectric dams on the tropical aquatic ecosystem. It is also of scientific importance to investigate and evaluate the hydrological and physicochemical characteristics of a downstream river induced by river impoundment and operation of hydroelectric dam, which could have an impact on the fish community. In addition, knowledge on fish assemblages in the regulated downstream river of a dam coupled with growth pattern and well-being of fishes in the stream is also crucial for ecosystem conservation and management.

The Batang Ai Dam is the oldest dam built for electricity supply in the state of Sarawak, Malaysia. The reservoir has been impounded for more than 30 years. Several studies on water quality of the reservoir have been conducted [1518]. However, knowledge on its downstream river below the powerhouse is scarce. The influence of the impoundment and the erratic discharge of the reservoir water during power generation on its downstream river remain unknown. Hence, this study aimed to establish the baseline data on hydrological 


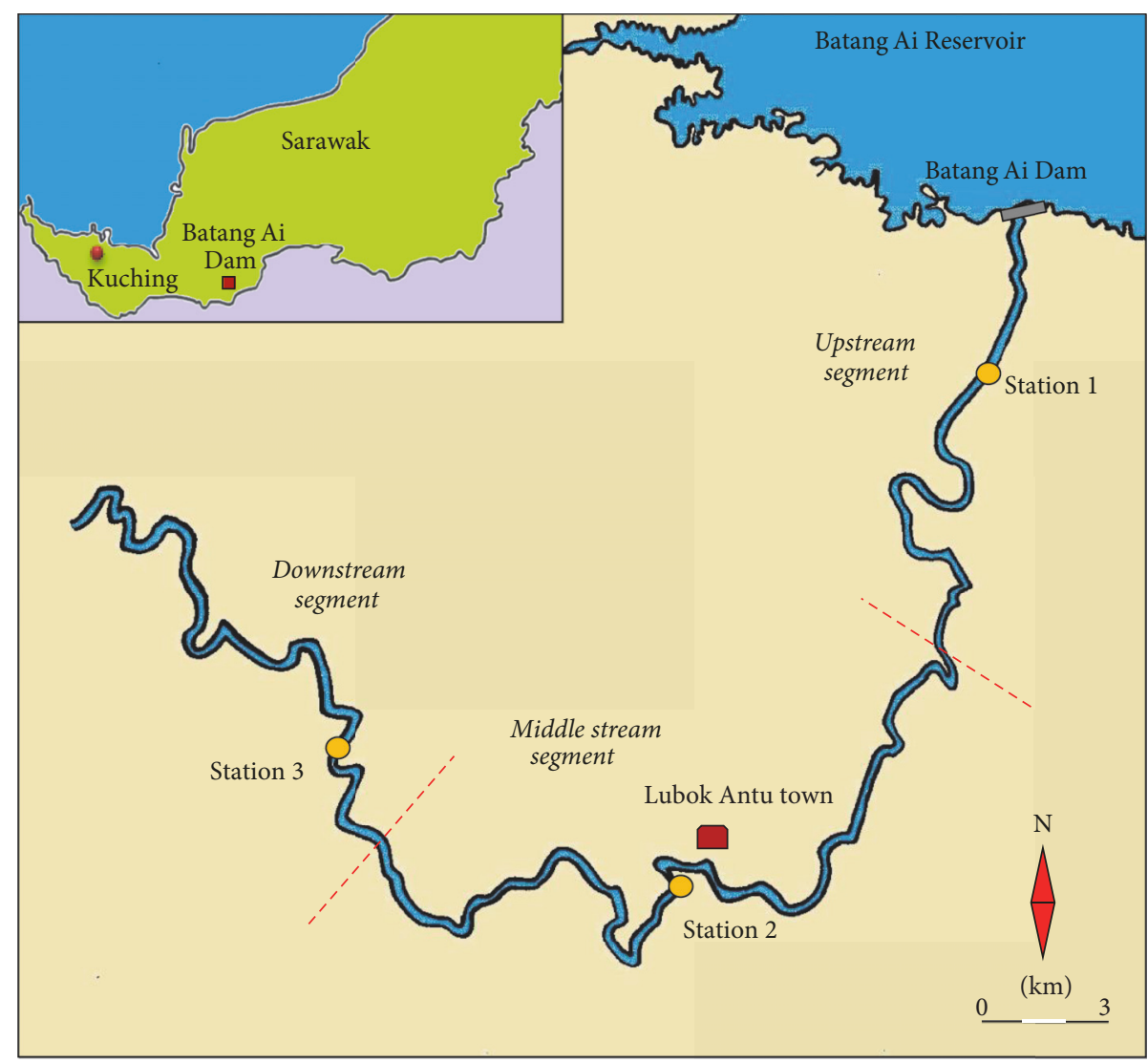

FIGURE 1: Location of the three segments and sampling stations in the study area.

characteristics, physicochemical parameters of water, and fish fauna composition in the downstream river, which was subjected to diurnal discharge of reservoir water during power generation. Additionally, the length-weight relationship and Fulton's condition factor of the three most dominant fish species in the downstream river were determined.

\section{Materials and Methods}

2.1. Study Area and Sampling Location. The present study was conducted in the downstream river of the Batang Ai Dam located in Lubok Antu, Sarawak, Malaysia, approximately $250 \mathrm{~km}$ southeast of Kuching (Figure 1). The Batang Ai Dam was constructed across Batang Ai (Batang means large river) and was commissioned in 1985. It serves as a hydropower dam and the reservoir is also used for aquaculture and tourism activities. The stretch of the river that was studied started at the powerhouse and stretched $30 \mathrm{~km}$ downstream from it. This stretch was divided into three segments, namely, upstream segment, middle stream segment, and downstream segment. Each segment covered a distance of about $10 \mathrm{~km}$. The river was subjected to diurnal fluctuation of flow, where the discharge through turbines mainly occurs during daytime. Subsistence agricultural activities and settlements in longhouses are located along the river. In addition, the middle stream segment of the river passes through a small town, Lubok Antu, as well as a road.
2.2. Field Samplings and Laboratory Analysis. Data on fish fauna and water quality were collected in October 2014, January 2015, and February 2017. The hydrological characteristics for each segment were studied in February 2017. The width, depth, and velocity of the river were measured at three different time frames in a day by using a range finder (Bushnell Elite 1500), a depth finder (Speedtech), and a flow meter (Flowatch FL-03), respectively.

$\mathrm{pH}$, temperature, electrical conductivity, dissolved oxygen (DO), and turbidity were measured in triplicate by using a $\mathrm{pH}$ meter with a temperature probe (SDL100 Extech Instrument), a conductivity meter (Lutron CD-4303), a DO meter (SDL150 Extech Instrument), and a turbidity meter (TU-2016 Lutron), respectively. Triplicate water samples were taken for the analyses of total suspended solids (TSS), fiveday biochemical oxygen demand $\left(\mathrm{BOD}_{5}\right)$, and chlorophyll $a$ ( $\mathrm{chl} a$ ) following the procedure of Jenkins et al. [19]. TSS was calculated as the difference between the initial weight and final weight of the $0.7 \mu \mathrm{m}$ retention glass microfibre filter (Advantec) after the filtration of one liter of water sample and drying to constant weight at $105^{\circ} \mathrm{C} . \mathrm{BOD}_{5}$ was determined as the difference between the initial and final DO concentrations after a five-day long incubation of the sample at $20^{\circ} \mathrm{C}$. Chl $a$ was determined from samples filtered through a $0.45 \mu \mathrm{m}$ retention glass microfibre filter (Sartorius) and extracted for $24 \mathrm{~h}$ using $90 \%(\mathrm{v} / \mathrm{v})$ acetone.

Fish samples were collected using two types of gill nets, namely, monofilament gill net and three-layered gill net. The 
TABLE 1: Hydrological characteristics in the three segments of Batang Ai below the dam.

\begin{tabular}{|c|c|c|c|c|c|c|c|c|c|}
\hline \multirow{2}{*}{ Parameter } & \multicolumn{3}{|c|}{ Upstream } & \multicolumn{3}{|c|}{ Middle stream } & \multicolumn{3}{|c|}{ Downstream } \\
\hline & 0840 & 1500 & 2000 & 0740 & 1020 & 1806 & 0940 & 1222 & 1530 \\
\hline Mean depth, m & 0.55 & 0.90 & 0.96 & 1.22 & 0.89 & 2.17 & 0.79 & 0.96 & 0.72 \\
\hline Mean velocity, $\mathrm{m} / \mathrm{s}$ & 0.07 & 0.50 & 1.00 & 0.22 & 0.37 & 0.88 & 0.68 & 0.80 & 0.60 \\
\hline Flow, $\mathrm{m}^{3} / \mathrm{s}$ & 1.90 & 26.23 & 53.50 & 15.25 & 18.56 & 86.14 & 17.29 & 25.30 & 13.74 \\
\hline
\end{tabular}

monofilament gill net consisted of four different mesh sizes $(2.5 \mathrm{~cm}, 5.1 \mathrm{~cm}, 7.2 \mathrm{~cm}$, and $10.2 \mathrm{~cm})$ and each had a length of $45.0 \mathrm{~m}$. The three-layered gill net had mesh sizes of $14.0 \mathrm{~cm}$, $4.0 \mathrm{~cm}$, and $14.0 \mathrm{~cm}$ with a length of $65.0 \mathrm{~m}$. For each sampling trip, equal numbers of nets were placed and left for two nights in each segment and the nets were checked twice daily during daytime. The fish specimens collected were fixed in $10 \%$ formalin and later transferred into $70 \%$ ethanol for preservation. Fish specimens were sorted and enumerated according to sampling station and species identified according to the taxonomic keys $[20,21]$ and an online global database of fish species [22]. The total length (TL) and body weight (BW) of the three most abundant fish species were measured to the nearest millimeter and gram, respectively.

2.3. Data and Statistical Analysis. The flow, mean depth, and mean velocity of the river were calculated according to Chapra [23]. The water quality parameters collected in the three segments were compared by using one-way ANOVA, where the sampling trip was treated as a random effect in the analysis followed by Tukey's test, where $P \leq 0.05$ indicated significant difference. The fish data collected during the three sampling trips at each segment were pooled to calculate the fish abundance in each segment. Species diversity, evenness, and richness were calculated using the following formulas.

Shannon's diversity index $(H)[24]$ is given as follows:

$$
H=\sum \frac{N_{i}}{N} \log _{e} \frac{N_{i}}{N}
$$

Pielou's evenness $(J)[25]$ is given as follows:

$$
J=\frac{H}{\log _{e} S} .
$$

Margalef's index of species richness (D) [26] is given as follows:

$$
D=\frac{S-1}{\log _{e} N},
$$

where $N$ is the sample size, $N_{i}$ is the number of specimens per species, and $S$ is the total number of species.

The length-weight relationship (LWR) and the general well-being of fish expressed by Fulton's condition factor $(K)$ of the three most abundant species were determined. The LWR of fish species was established using the formula $\mathrm{BW}=a \mathrm{TL}^{n}$ by expressing it in the logarithmic form as $\log \mathrm{BW}=\log a+$ $n \log$ TL [27]. The statistical significance of the relationship was determined by using linear regression analysis with $P \leq$ 0.05 , where the constants " $a$ " and " $n$ " were obtained. Fulton's condition factor $(K)[28]$ was calculated using the following formula:

$$
K=\frac{\mathrm{BW} \times 100}{\mathrm{TL}^{3}}
$$

Pearson's correlation analysis was performed to elucidate significant relationship among the biotic and abiotic parameters at $P \leq 0.10$. All the statistical analyses were carried out using the Statistical Package for Social Sciences (SPSS version 24, SPSS Inc., 1995).

\section{Results and Discussion}

3.1. Hydrological Characteristics of the Downstream River of Batang Ai Dam. The hydrological characteristics of the downstream river of the dam varied substantially in a day due to the regulation of water discharge through the turbines during power generation and no water was released from the spillway. Prior to the discharge in the morning, the river was shallow and moved slowly, particularly in the upstream segment, with a mean depth of $0.55 \mathrm{~m}$, a mean velocity of $0.07 \mathrm{~m} / \mathrm{s}$, and an estimated discharge of $1.90 \mathrm{~m}^{3} / \mathrm{s}$ (Table 1). The mean velocity and flow gradually increased towards the downstream direction with the highest mean velocity of $0.68 \mathrm{~m} / \mathrm{s}$ and the highest flow of $17.29 \mathrm{~m}^{3} / \mathrm{s}$ observed in the downstream segment. When the water was discharged from the reservoir into the downstream river during power generation, the mean depth, mean velocity, and flow increased substantially in the upstream and middle stream segments. The mean depth, mean velocity, and flow in the upstream segment were found to increase to $0.90 \mathrm{~m}$, $0.50 \mathrm{~m} / \mathrm{s}$, and $26.23 \mathrm{~m}^{3} / \mathrm{s}$, respectively, at $1500 \mathrm{hrs}$. The water discharge continues to affect the mean velocity and flow in the upstream segment, where they increased up to $1.00 \mathrm{~m} / \mathrm{s}$ and $53.50 \mathrm{~m}^{3} / \mathrm{s}$, respectively, at $2000 \mathrm{hrs}$. In middle stream segment, the impact of the water discharge was observed at around $1800 \mathrm{hrs}$, where the mean depth, mean velocity, and flow increased up to $2.17 \mathrm{~m}, 0.88 \mathrm{~m} / \mathrm{s}$, and $86.14 \mathrm{~m}^{3} / \mathrm{s}$, respectively. There was no noticeable variation in the hydrological characteristics of the downstream segment as the discharge had not reached the downstream segment yet.

3.2. Physicochemical Parameters of the Water of the Downstream River of Batang Ai Dam. Water quality at the downstream river was significantly different $(P \leq 0.05)$ among segments along the river (Table 2). The lowest $\mathrm{pH}$ value of 6.4 was recorded in the upstream segment and significantly increased $(P \leq 0.05)$ to 6.8 in the middle stream and downstream segments. The $\mathrm{pH}$ value was classified as Class II according to the Water Quality Index (WQI) of Malaysia [29]. The lower $\mathrm{pH}$ value in the upstream segment is due to the 
TABLE 2: Means and standard deviations of the physicochemical characteristics of the downstream river of Batang Ai.

\begin{tabular}{lccc}
\hline Parameter & Upstream & Middle stream & Downstream \\
\hline $\mathrm{pH}$ & $6.4^{\mathrm{a}} \pm 0.2$ & $6.8^{\mathrm{b}} \pm 0.2$ & $6.8^{\mathrm{b}} \pm 0.4$ \\
Temperature & $29.0^{\mathrm{c}} \pm 1.4$ & $28.0^{\mathrm{b}} \pm 1.6$ & $26.8^{\mathrm{a}} \pm 0.7$ \\
Conductivity & $23.9^{\mathrm{b}} \pm 5.3$ & $25.4^{\mathrm{c}} \pm 5.0$ & $21.8^{\mathrm{a}} \pm 5.7$ \\
DO & $5.9^{\mathrm{a}} \pm 1.7$ & $6.2^{\mathrm{b}} \pm 1.5$ & $6.3^{\mathrm{c}} \pm 1.4$ \\
Turbidity & $3.8^{\mathrm{a}} \pm 0.8$ & $4.6^{\mathrm{a}} \pm 1.3$ & $15.4^{\mathrm{b}} \pm 14.9$ \\
TSS & $4.4^{\mathrm{a}} \pm 0.5$ & $11.7^{\mathrm{ab}} \pm 13.9$ & $12.4^{\mathrm{b}} \pm 11.6^{\mathrm{b}}$ \\
$\mathrm{BOD}$ & $3.5^{\mathrm{b}} \pm 0.2$ & $2.6^{\mathrm{a}} \pm 1.4$ & $2.6^{\mathrm{a}} \pm 1.2^{\mathrm{a}}$ \\
Chl $a$ & $2.5^{\mathrm{a}} \pm 0.9$ & $2.1^{\mathrm{a}} \pm 0.4$ & $2.4^{\mathrm{a}} \pm 1.4$ \\
\hline
\end{tabular}

Mean followed by different letters indicated significant difference at $P \leq 0.05$.

intake of lower $\mathrm{pH}$ water from hypolimnion of the reservoir during power generation. In Batang Ai Dam, the water intake for power operation is about $14 \mathrm{~m}$ below the surface, where the $\mathrm{pH}$ is predominantly acidic [15]. The increase in $\mathrm{pH}$ value at middle stream and downstream segments is attributable to dilution effect [30]. Water temperature ranged from 26.8 $\pm 0.7^{\circ} \mathrm{C}$ to $29.0 \pm 1.4^{\circ} \mathrm{C}$, where it decreased significantly $(P \leq 0.05)$ with distance from the dam. Changes in water temperature of the downstream river of a hydropower plant occurred when warmer or colder water of a reservoir was being released into its downstream river [31, 32]. Bobat [31] stated that the downstream water of dams and hydropower plants was generally warmer than upstream water because of the passing of water from pipelines, penstock, turbine, and cooling system into the downstream river. However, Ling et al. [16] showed that the water temperature of river located at outflow of the Batang Ai reservoir was colder than the reservoir water. Hence, it is hypothesized that warm water in upstream segment in the present study is due to direct solar radiation in the shallow and exposed river. As river depth increased in middle stream and downstream segments, the heat capacity per unit surface area increased and thus a decrease in water temperature was observed [33].

Mean conductivity values at the segments ranged from $21.8 \pm 5.7 \mu \mathrm{S} / \mathrm{cm}$ to $25.4 \pm 5.0 \mu \mathrm{S} / \mathrm{cm}$ and they were significantly different $(P \leq 0.05)$ (Table 2$)$. The highest value of conductivity was observed in the middle stream segment. Similar to $\mathrm{pH}$ value, the DO values in the downstream river also increased significantly with distance from the dam $(P \leq$ $0.05)$, that is, from $5.9 \pm 1.7 \mathrm{mg} / \mathrm{L}$ in upstream segment to $6.3 \pm 1.4 \mathrm{mg} / \mathrm{L}$ in downstream segment. The increase in DO value further from the powerhouse indicates that the $\mathrm{DO}$ content was first impacted by the low DO from the reservoir but was later diluted by river water with higher DO content as well as reaeration due to faster water flow along the river. The mean DO values met the minimum requirement for healthy sensitive aquatic organisms $(5 \mathrm{mg} / \mathrm{L})$ at all segments and are classified as Class II. However, low DO values of less than $5 \mathrm{mg} / \mathrm{L}$ were observed occasionally in the downstream river during samplings. This is due to the lower value of DO from deeper water column of the reservoir. At the water intake depth of $14 \mathrm{~m}$, DO has been reported to be $3.92 \mathrm{mg} / \mathrm{L}$ [15]. Factors responsible for the large variations in DO value among trips were seasonal variations in precipitation, which resulted in changes in river flow rate and the differences in discharge during power generation. This is further supported by the significant correlation $(r=+0.993 ; P \leq 0.10)$ between DO and flow observed in the present study.

Turbidity and TSS values were low in the downstream river, ranging from $3.8 \pm 0.8 \mathrm{NTU}$ to $15.4 \pm 14.9 \mathrm{NTU}$ and from $4.4 \pm 0.5 \mathrm{mg} / \mathrm{L}$ to $12.4 \pm 11.6 \mathrm{mg} / \mathrm{L}$, respectively. Both parameters were classified as Class I and/or Class II according to WQI. The low turbidity and TSS values in the present study were different from the high turbidity and TSS values observed in the downstream river of a new hydroelectric dam [30]. However, they are consistent with low turbidity (2-15 NTU) and TSS values $(2-7 \mathrm{mg} / \mathrm{L})$ recorded in the Batang Ai reservoir at 10 and $20 \mathrm{~m}$ depths [17], as suspended solids have settled at this 30-year-old reservoir [16]. Among the segments studied, turbidity and TSS values were significantly higher $(P \leq 0.05)$ in downstream segment than in upstream segment. TSS was significantly and positively correlated $(r=+0.999 ; P \leq 0.05)$ with flow (Table 3), indicating resuspension of sediment under higher flow rate in downstream segment, which was likely the cause of higher turbidity and TSS values in the downstream segment.

$\mathrm{BOD}_{5}$ showed an opposite trend with turbidity and TSS values, where the mean decreased significantly from $3.5 \mathrm{mg} / \mathrm{L}$ in upstream segment to $2.6 \mathrm{mg} / \mathrm{L}$ in middle stream and downstream segments. $\mathrm{BOD}_{5}$ concentration was classified as Class III in upstream segment and Class II in middle stream and downstream segments. The gradual decrease of $\mathrm{BOD}_{5}$ concentration further downstream indicates that $\mathrm{BOD}_{5}$ was most probably contributed by the reservoir water as high $\mathrm{BOD}_{5}$ concentration $(6.33 \mathrm{mg} / \mathrm{L})$ had been reported in the outflow of the reservoir [16]. This is further supported by the significant and negative correlation $(r=-0.993 ; P \leq 0.10)$ between $\mathrm{BOD}_{5}$ and flow. Chl $a$ concentration was relatively constant along the river with a mean value of $2.3 \mathrm{mg} / \mathrm{m}^{3}$ as the analysis shows that there was no significant difference $(P>0.05)$ among the segments.

3.3. Fish Assemblage of the Downstream River of the Batang Ai Dam. A total of 436 fish individuals belonging to eight families, 13 genera, and 17 species were captured in the downstream river of Batang Ai (Table 4). The results show that the most dominant family is Cyprinidae (67.9\%) followed by Bagridae (11.2\%). The three most dominant species were Cyclocheilichthys apogon (48.2\%) and Hampala macrolepidota (11.0\%) from the family Cyprinidae and Hemibagrus planiceps $(10.8 \%)$ from the family Bagridae. Shannon's diversity index of 1.9 and the richness index of 2.6 show that fish diversity and species richness in the downstream river were low [34]. 
TABLE 3: Correlation between abiotic and biotic parameters at downstream river of Batang $\mathrm{Ai}(N=3)$.

\begin{tabular}{|c|c|c|c|c|c|c|c|c|c|c|c|c|c|}
\hline & $\mathrm{pH}$ & Temp. & Cond. & Turb. & $\mathrm{DO}$ & TSS & $\mathrm{BOD}_{5}$ & Chl $a$ & Flow & Mean depth & Abundance & $H$ & $D$ \\
\hline $\mathrm{pH}$ & 1.000 & & & & & & & & & & & & \\
\hline Temp. & -0.839 & 1.000 & & & & & & & & & & & \\
\hline Cond. & -0.096 & 0.623 & 1.000 & & & & & & & & & & \\
\hline Turb. & 0.553 & -0.917 & -0.883 & 1.000 & & & & & & & & & \\
\hline DO & 0.971 & -0.945 & -0.332 & 0.737 & 1.000 & & & & & & & & \\
\hline TSS & $0.997^{* *}$ & -0.879 & -0.174 & 0.617 & $0.987^{*}$ & 1.000 & & & & & & & \\
\hline $\mathrm{BOD}_{5}$ & $-1.000^{* *}$ & 0.839 & 0.096 & -0.553 & -0.971 & $-0.997^{* *}$ & 1.000 & & & & & & \\
\hline Chl $a$ & -0.693 & 0.189 & -0.651 & 0.218 & -0.500 & -0.634 & 0.693 & 1.000 & & & & & \\
\hline Flow & $0.993^{*}$ & -0.899 & -0.217 & 0.650 & $0.993^{*}$ & $0.999^{* *}$ & $-0.993^{*}$ & -0.600 & 1.000 & & & & \\
\hline Mean depth & 0.774 & -0.304 & 0.556 & -0.100 & 0.599 & 0.721 & -0.774 & $-0.993^{*}$ & 0.691 & 1.000 & & & \\
\hline Abundance & 0.920 & -0.985 & -0.478 & 0.835 & $0.987^{*}$ & 0.948 & -0.920 & -0.356 & 0.961 & 0.464 & 1.000 & & \\
\hline$H$ & 0.713 & -0.216 & 0.630 & -0.190 & 0.524 & 0.656 & -0.713 & $-1.000^{* *}$ & 0.622 & $0.996^{*}$ & 0.382 & 1.000 & \\
\hline$D$ & 0.531 & 0.017 & 0.793 & -0.413 & 0.312 & 0.462 & -0.531 & -0.979 & 0.423 & 0.947 & 0.156 & 0.973 & 1.000 \\
\hline
\end{tabular}

${ }^{*} P \leq 0.10 ;{ }^{* *} P \leq 0.05$.

TABLE 4: Summary of the fish assemblages at the downstream river of Batang Ai.

\begin{tabular}{|c|c|c|c|c|c|c|c|c|c|}
\hline \multirow{2}{*}{ Family } & \multirow{2}{*}{ Species } & \multicolumn{2}{|c|}{ Upstream } & \multicolumn{2}{|c|}{ Middle stream } & \multicolumn{2}{|c|}{ Downstream } & \multicolumn{2}{|c|}{ Total } \\
\hline & & Count & $\%$ & Count & $\%$ & Count & $\%$ & Count & $\%$ \\
\hline \multirow{2}{*}{ Bagridae } & Hemibagrus nigriceps & 0 & 0 & 2 & 1 & 0 & 0 & 2 & 0.5 \\
\hline & Hemibagrus planiceps & 15 & 17 & 16 & 10 & 16 & 8 & 47 & 10.8 \\
\hline Channidae & Channa striata & 1 & 1 & 6 & 4 & 1 & 1 & 8 & 1.8 \\
\hline Clariidae & Clarias batrachus & 3 & 3 & 2 & 1 & 2 & 1 & 7 & 1.6 \\
\hline \multirow{9}{*}{ Cyprinidae } & Barbonymus schwanenfeldii & 3 & 3 & 1 & 1 & 2 & 1 & 6 & 1.4 \\
\hline & Cyclocheilichthys apogon & 45 & 52 & 70 & 46 & 95 & 48 & 210 & 48.2 \\
\hline & Cyclocheilichthys armatus & 1 & 1 & 2 & 1 & 0 & 0 & 3 & 0.7 \\
\hline & Hampala macrolepidota & 5 & 6 & 16 & 10 & 27 & 14 & 48 & 11.0 \\
\hline & Osteochilus enneaporos & 0 & 0 & 0 & 0 & 1 & 1 & 1 & 0.2 \\
\hline & Osteochilus schlegelii & 0 & 0 & 1 & 1 & 0 & 0 & 1 & 0.2 \\
\hline & Osteochilus waandersii & 0 & 0 & 6 & 4 & 4 & 2 & 10 & 2.3 \\
\hline & Puntius binotatus & 3 & 3 & 2 & 1 & 5 & 3 & 10 & 2.3 \\
\hline & Rasbora caudimaculata & 3 & 3 & 4 & 3 & 0 & 0 & 7 & 1.6 \\
\hline Eleotridae & Oxyeleotris marmorata & 5 & 6 & 5 & 3 & 8 & 4 & 18 & 4.1 \\
\hline Mastacembelidae & Mastacembelus erythrotaenia & 0 & 0 & 5 & 3 & 3 & 2 & 8 & 1.8 \\
\hline Osphronemidae & Osphronemus goramy & 3 & 3 & 14 & 9 & 23 & 12 & 40 & 9.2 \\
\hline Toxotidae & Toxotes microlepis & 0 & 0 & 1 & 1 & 9 & 5 & 10 & 2.3 \\
\hline \multicolumn{2}{|c|}{ Total number of species } & 11 & 100 & 16 & 100 & 13 & 100 & 17 & 100 \\
\hline \multicolumn{2}{|c|}{ Total number of fish caught } & 87 & & 153 & & 196 & & 436 & \\
\hline \multicolumn{2}{|c|}{ Shannon's diversity index, $H(e)$} & 1.7 & & 1.9 & & 1.7 & & 1.9 & \\
\hline \multicolumn{2}{|c|}{ Margalef's richness index, $D(e)$} & 2.2 & & 3.0 & & 2.3 & & 2.6 & \\
\hline \multicolumn{2}{|c|}{ Pielou’s evenness index, $J(e)$} & 0.7 & & 0.7 & & 0.7 & & 0.7 & \\
\hline
\end{tabular}

The highest diversity and species richness were found in the middle stream segment. In the downstream river, an evenness index of 0.7 shows that the fish compositions are considered to be more evenly distributed [25].

The present study shows that fish abundance increased with an increasing distance from the dam. A total of 87,153 , and 194 individuals were caught in the upstream, middle stream, and downstream segments, respectively. Reduced biotic abundance, diversity, and productivity in tail water may be due directly to flow variation or indirectly to factors related to flow variation such as changes in river depth and temperature [35]. In the present study, fish abundance was significantly and positively correlated with DO $(r=+0.987$; $P \leq 0.10)$. This indicates that lower DO content in the upstream segment plays a significant role in the reduction of fish abundance in that segment. The fish abundance increased when DO improved in the downstream direction. As DO was influenced by the river flow, fish abundance in the study area was indirectly influenced by the flow as well. However, there is no strong relationship found between fish abundance and flow in the present study. Similarly, Growns [12] reported that the abundance of individual fish species was only weakly correlated with the index of flow deviation and river hydrology and thus explained only a small part of variation in fish assemblage structure. The species diversity was found to be significantly and positively correlated with the river mean depth $(r=+0.996 ; P \leq 0.10)$. The result indicates that fish assemblage in a shallow river in the upstream segment is less diverse than a deeper river in middle stream and downstream segments.

Table 5 summarizes the LWR analysis conducted on the three most dominant species in the downstream river of 


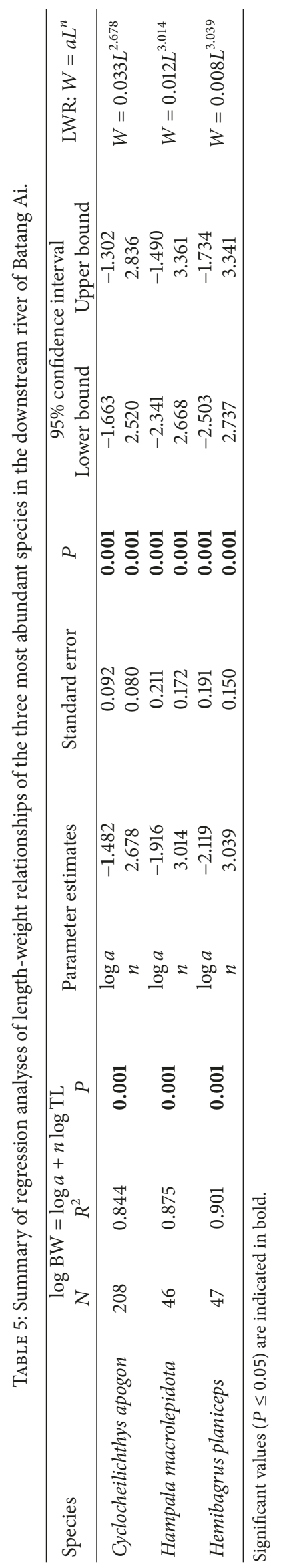




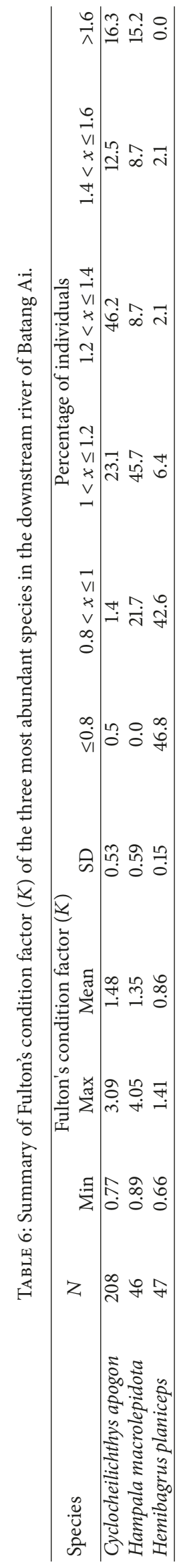


the Batang Ai Dam. Significant linear regressions with $R^{2}$ close to the value of one show that TL and BW of each species fitted the linear model well. The LWRs for C. apogon, $H$. macrolepidota, and $H$. planiceps are expressed as $W=$ $0.033 L^{2.678}, W=0.012 L^{3.014}$, and $W=0.008 \mathrm{~L}^{3.039}$, respectively. The most dominant species, C. apogon, exhibited a negative allometric growth (coefficient " $n$ " value $<3$ ), whereas $H$. macrolepidota and $H$. planiceps exhibited an isometric growth as indicated by the " $n$ " values of 3 .

Fulton's condition factor $(K)$ value gradually decreased from the most abundant species, C. apogon (1.48 \pm 0.53$)$, to the third most abundant species, $H$. planiceps $(0.86 \pm 0.15)$ (Table 6). Around $46.2 \%$ of the $K$ values of $C$. apogon were found in the range of 1.2-1.4, which indicates that nearly half of the fish in this species were in good condition. On the other hand, $45.7 \%$ of $H$. macrolepidota scored $K$ values between 1.0 and 1.2, indicating that nearly half of this species caught were in fair condition. However, most of the $K$ values of $H$. planiceps $(89.4 \%)$ were $\leq 1$, indicating poor to extremely poor conditions [36]. Food availability and environmental condition are most likely the reasons for the well-being of those species. The most abundant fish species, C. apogon, thrived better in the downstream river of Batang Ai compared to other species.

\section{Conclusions}

The present study shows that water discharge regulation of the Batang Ai Dam affected the hydrological characteristics, physicochemical parameters of water, and fish assemblages of its downstream river. The downstream river was extremely shallow and moved slowly but the mean depth, velocity, and flow of the river increased substantially when water was discharged from the dam during power generation. Physicochemical parameters of water, particularly $\mathrm{pH}, \mathrm{DO}$, TSS, and $\mathrm{BOD}_{5}$ concentrations, were impacted by the dam water discharge as indicated by the significant correlation between those parameters and flows. The three most abundant fish species were C. apogon (48.2\%) and H. macrolepidota (11.0\%) of family Cyprinidae followed by $H$. planiceps (10.8\%) of family Bagridae. Fish abundance was low in upstream segment but gradually increased in the downstream direction, away from the dam. Fish abundance was significantly correlated with DO, whereas the fish diversity was influenced by the river depth. Length-weight relationship analyses show that C. apogon exhibited negative allometric growth, whereas $H$. macrolepidota and $H$. planiceps exhibited isometric growth.

\section{Conflicts of Interest}

The authors declare that there are no conflicts of interest regarding the publication of this paper.

\section{Acknowledgments}

The authors appreciate the financial support provided by Sarawak Energy Berhad through Grant no. GL (F07)/SEB/ $5 \mathrm{~A} / 2013(28)$ and the facilities provided by Universiti Malaysia Sarawak.

\section{References}

[1] P. McCully, "Rivers no more: the environmental effects of dams," in Silenced Rivers: The Ecology and Politics of Large Dams, P. McCully, Ed., pp. 29-64, Zed Books, London, UK, 1996.

[2] W. Wildi, "Environmental hazards of dams and reservoirs," in Near Curriculum in Natural Environmental Science, vol. 88 of Geneva: Section des sciences de la Terre et de l'environnement, pp. 187-197, Geneva, Switzerland, 2010.

[3] Y. Yi, Z. Yang, and S. Zhang, "Ecological influence of dam construction and river-lake connectivity on migration fish habitat in the Yangtze River basin, China," Procedia Environmental Sciences, vol. 2, no. 5, pp. 1942-1954, 2010.

[4] Q. Lin, "Influence of dams on river ecosystem and its countermeasures," Journal of Water Resource and Protection, vol. 03, no. 01, pp. 60-66, 2011.

[5] M. W. Beck, A. H. Claassen, and P. J. Hundt, "Environmental and livelihood impacts of dams: common lessons across development gradients that challenge sustainability," International Journal of River Basin Management, vol. 10, no. 1, pp. 73-92, 2012.

[6] G. L. Wei, Z. F. Yang, B. S. Cui et al., "Impact of dam construction on water quality and water self-purification capacity of the Lancang River, China," Water Resources Management, vol. 23, no. 9, pp. 1763-1780, 2009.

[7] Y. Zhang, J. Xia, T. Liang, and Q. Shao, "Impact of water projects on river flow regimes and water quality in Huai River Basin," Water Resources Management, vol. 24, no. 5, pp. 889-908, 2010.

[8] M. Wiatkowski, "Influence of słup dam reservoir on flow and quality of water in the Nysa Szalona river," Polish Journal of Environmental Studies, vol. 20, no. 2, pp. 469-478, 2011.

[9] H. Guo, Q. Hu, Q. Zhang, and S. Feng, "Effects of the three gorges dam on yangtze river flow and river interaction with poyang lake, China: 2003-2008," Journal of Hydrology, vol. 416417, pp. 19-27, 2012.

[10] Q. Zhao, S. Liu, L. Deng et al., "Landscape change and hydrologic alteration associated with dam construction," International Journal of Applied Earth Observation and Geoinformation, vol. 16, no. 1, pp. 17-26, 2012.

[11] L. Feng, X. Sun, and X. Zhu, "Impact of floodgates operation on water environment using one-dimensional modelling system in river network of Wuxi city, China," Ecological Engineering, vol. 91, pp. 173-182, 2016.

[12] I. Growns, "The influence of changes to river hydrology on freshwater fish in regulated rivers of the Murray-Darling basin," Hydrobiologia, vol. 596, no. 1, pp. 203-211, 2008.

[13] X. Li, S. Dong, Q. Zhao, and S. Liu, "Impacts of manwan dam construction on aquatic habitat and community in middle reach of lancang river," Procedia Environmental Sciences, vol. 2, no. 5, pp. 706-712, 2010.

[14] A. M. Latifah and L. Met, "An ecological evaluation approach for dam project development in Malaysia," Life Science Journal, vol. 11, no. 7, pp. 225-237, 2014.

[15] T. Y. Ling, D. P. Debbie, N. Lee, I. Norhadi, and J. J. E. Justin, "Water quality at Batang Ai Hydroelectric Reservoir (Sarawak, Malaysia) and implications for aquaculture," vol. 2, pp. 23-30, 2012.

[16] T.-Y. Ling, L. Nyanti, C.-K. Leong, and Y.-M. Wong, "Comparison of water quality at different locations at Batang Ai Reservoir, Sarawak, Malaysia," World Applied Sciences Journal, vol. 26, no. 11, pp. 1473-1481, 2013. 
[17] T. Y. Ling, T. Z. E. Lee, and L. Nyanti, "Phosphorus in batang ai hydroelectric dam Reservoir, Sarawak, Malaysia," World Applied Sciences Journal, vol. 28, no. 10, pp. 1348-1354, 2013.

[18] L. Nyanti, K. M. Hii, A. Sow, I. Norhadi, and T. Y. Ling, "Impacts of aquaculture at different depths and distances from cage culture sites in Batang Ai hydroelectric dam reservoir, Sarawak, Malaysia," World Applied Sciences Journal, vol. 19, no. 4, pp. 451456, 2012.

[19] D. Jenkins, J. J. Connors, and A. E. Greenberg, Standard Methods for the Examination of Water and Wastewater, American Public Health Association, Washington DC, USA, 21st edition, 2005.

[20] T. R. Roberts, The Freshwater Fishes of Western Borneo (Kalimantan Barat, Indonesia), California Academy of Science, San Francisco, Calif, USA, 1989.

[21] M. Kottelat, A. J. Whitten, S. Kartikasari, and S. Wirjoatmodjo, Freshwater Fishes of Western Indonesia and Sulawesi, Periplus E., Hong Kong, China, 1993.

[22] R. Froese and D. Pauly, "FishBase. World Wide Web electronic publication," http://www.fishbase.org/, 2016.

[23] S. C. Chapra, Surface Water-Quality Modeling, McGraw- Hill Inc, New York, NY, USA, 1997.

[24] C. E. Shannon and W. Weaver, The Mathematical Theory of Communication, University of Illinois press, Urbana, Illinois, USA, 1963.

[25] E. C. Pielou, "Species-diversity and pattern-diversity in the study of ecological succession," Journal of Theoretical Biology, vol. 10, no. 2, pp. 370-383, 1966.

[26] R. D. Margalef, Perspectives in Ecological Theory, University of Chicago Press, Chicago, USA, 1968.

[27] E. D. Le Cren, "The length-weight relationship and seasonal cycle in gonad weight and condition in the perch (Perca fluviatilis)," Journal of Animal Ecology, vol. 20, no. 2, pp. 201219, 1951.

[28] R. Froese, "Cube law, condition factor and weight-length relationships: history, meta-analysis and recommendations," Journal of Applied Ichthyology, vol. 22, no. 4, pp. 241-253, 2006.

[29] Department of Environment, "Malaysia Environmental Quality Report 2014," Tech. Rep., Kuala Lumpur, Malaysia, 2014.

[30] T.-Y. Ling, C.-L. Soo, T. L.-E. Heng, L. Nyanti, S.-F. Sim, and J. Grinang, "Physicochemical characteristics of river water downstream of a large tropical hydroelectric dam," Journal of Chemistry, vol. 2016, Article ID 7895234, pp. 1-7, 2016.

[31] A. Bobat, "Chapter 2: thermal pollution caused by hydropower plants," in Energy Systems and Management, Springer Proceedings in Energy, A. N. Bilge, Ed., pp. 19-33, Springer International Publishing, Switzerland, 2015.

[32] D. Carpentier, J. Haas, M. Olivares, and A. de la Fuente, "Modeling the multi-seasonal link between the hydrodynamics of a reservoir and its hydropower plant operation," Water (Switzerland), vol. 9, no. 6, article no. 367, pp. 1-18, 2017.

[33] J. C. Carron and H. Rajaram, "Impact of variable reservoir releases on management of downstream water temperatures," Water Resources Research, vol. 37, no. 6, pp. 1733-1743, 2001.

[34] A. E. Magurran, Ecological Diversity and Its Measurement, Croom Helm, London, UK, 1st edition, 1988.

[35] R. M. Cushman, "Review of ecological effects of rapidly varying flows downstream from hydroelectric facilities," North American Journal of Fisheries Management, vol. 5, pp. 330-339, 1985.

[36] C. Barnham and A. Baxter, "Condition factor, K, for salmonid fish,” Fisheries Notes, pp. 1-3, 1998. 

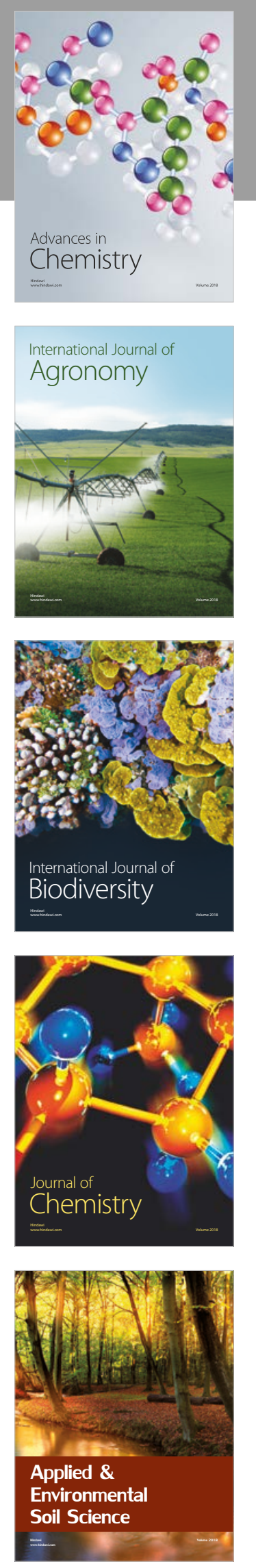

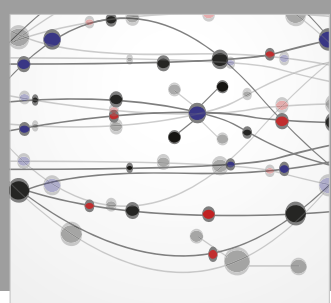

The Scientific World Journal

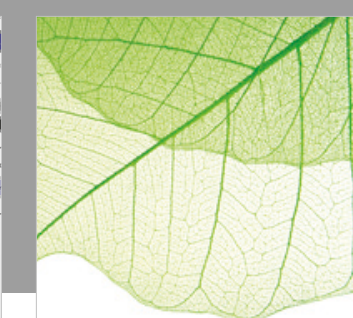

Journal of Botany

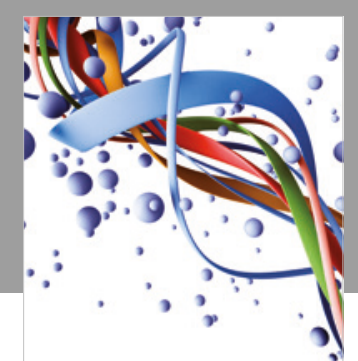

Scientifica

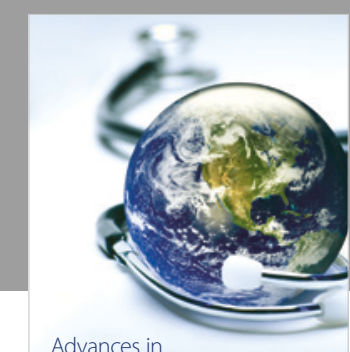

Public Health

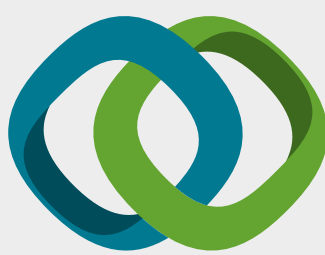

Hindawi

Submit your manuscripts at

www.hindawi.com
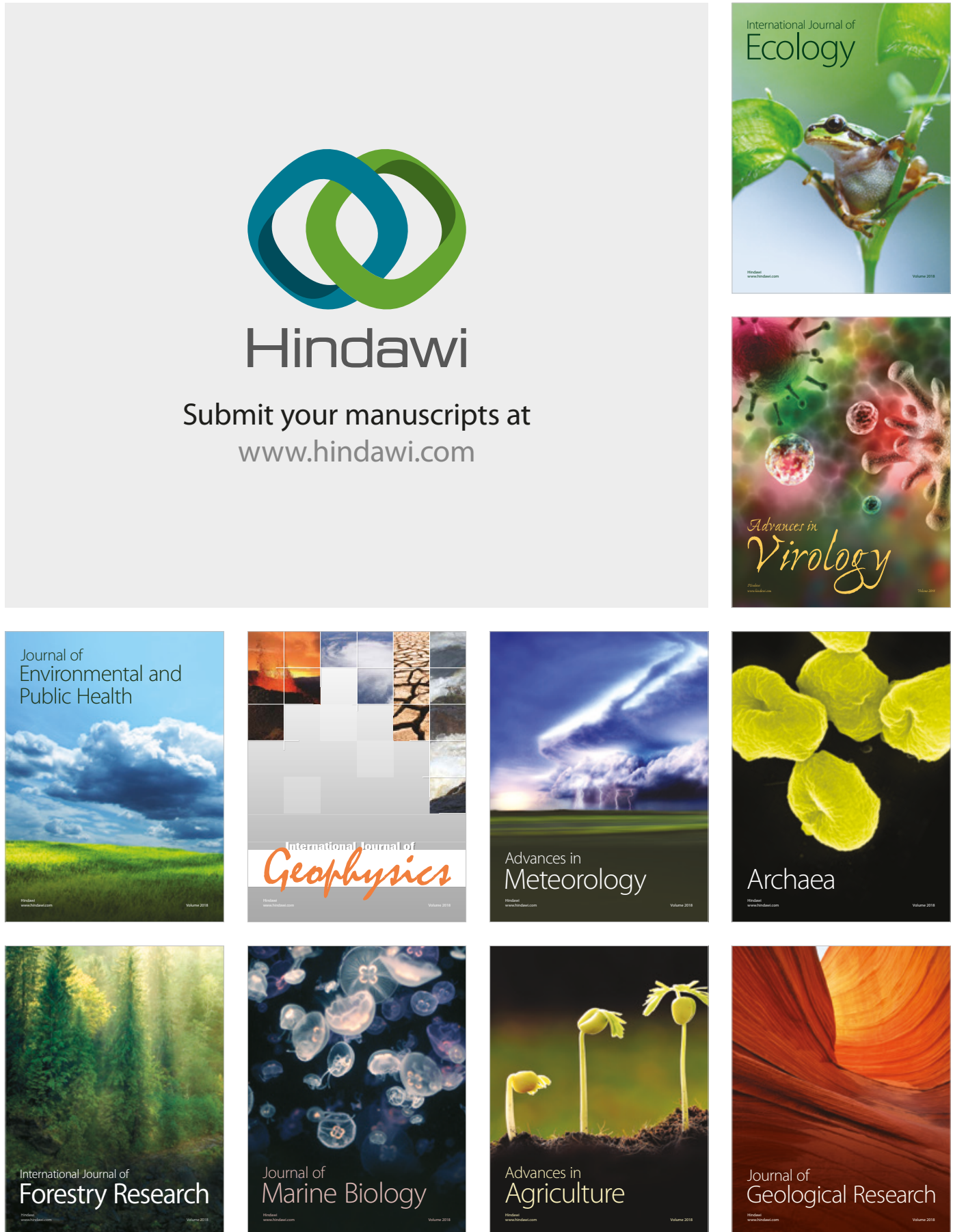

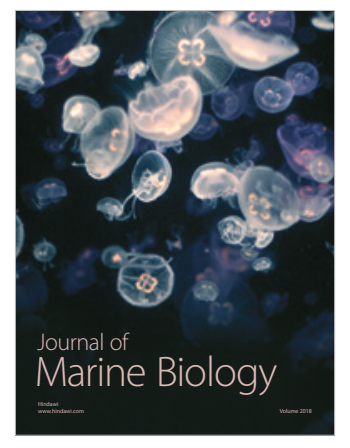

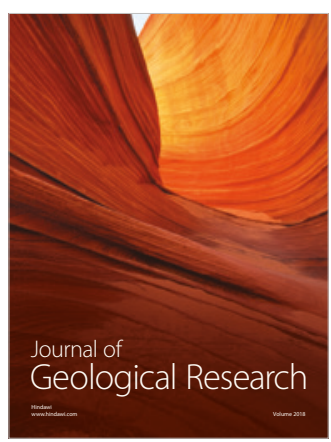

